\title{
Fungal specificity bottlenecks during orchid germination and development
}

\author{
MARTIN I. BIDARTONDO* and DAVID J.READ + \\ *Imperial College London \& Royal Botanic Gardens, Kew TW9 3DS, UK; †Animal and Plant Sciences, University of Sheffield, Sheffield \\ S10 2TN, UK
}

\begin{abstract}
Fungus-subsidized growth through the seedling stage is the most critical feature of the life history for the thousands of mycorrhizal plant species that propagate by means of 'dust seeds.' We investigated the extent of specificity towards fungi shown by orchids in the genera Cephalanthera and Epipactis at three stages of their life cycle: (i) initiation of germination, (ii) during seedling development, and (iii) in the mature photosynthetic plant. It is known that in the mature phase, plants of these genera can be mycorrhizal with a number of fungi that are simultaneously ectomycorrhizal with the roots of neighbouring forest trees. The extent to which earlier developmental stages use the same or a distinctive suite of fungi was unclear. To address this question, a total of 1500 packets containing orchid seeds were buried for up to 3 years in diverse European forest sites which either supported or lacked populations of helleborine orchids. After harvest, the fungi associated with the three developmental stages, and with tree roots, were identified via cultivation-independent molecular methods. While our results show that most fungal symbionts are ectomycorrhizal, differences were observed between orchids in the representation of fungi at the three life stages. In Cephalanthera damasonium and C. longifolia, the fungi detected in seedlings were only a subset of the wider range seen in germinating seeds and mature plants. In Epipactis atrorubens, the fungi detected were similar at all three life stages, but different fungal lineages produced a difference in seedling germination performance. Our results demonstrate that there can be a narrow checkpoint for mycorrhizal range during seedling growth relative to the more promiscuous germination and mature stages of these plants' life cycle.
\end{abstract}

Keywords: epiparasitism, myco-heterotrophy, symbiosis, Thelephoraceae

Received 17 February 2008; revision received 9 May 2008; accepted 28 May 2008

\section{Introduction}

In his seminal work on orchid pollination biology Darwin (1862) commented, 'The final end of the whole flower ... is the production of seed; and these are produced in orchids in vast profusion.' He went on to calculate that in Cephalanthera longifolia, a single flower could produce over 6000 seeds and that with this rate of production, assuming that all seeds germinated, 'an orchid's grandchildren could cover a space slightly exceeding the island of Anglesea.' Darwin, in recognizing that such proliferation of individual plants did not occur, characteristically identified the critical

Correspondence: Martin I. Bidartondo, Fax: 44 (0) 208332 5379;

E-mail: m.bidartondo@imperial.ac.uk biological question. He writes, 'What checks this unlimited multiplication cannot be told.'

We now know that the exceptionally numerous, extremely small and nearly devoid of nutritional reserves seeds of orchids (Arditti \& Ghani 2000) develop into mature plants thanks to a nutritional mode called myco-heterotrophy (Leake 1994), that is, seedlings are entirely nutritionally dependent upon fungi that colonize their cells. Thus, the availability of fungi may be expected to be a major factor preventing 'unlimited multiplication.' Myco-heterotrophic nutrition is evolutionarily widespread among plants and it can be a form of physiological epiparasitism when the fungi simultaneously colonize the roots of a myco-heterotrophic plant and neighbouring photosynthetic plants (Bidartondo 2005). Myco-heterotrophy in many nonphotosynthetic mycorrhizal plants is associated with high specificity towards 
narrow clades of fungi. In contrast, photosynthetic mycorrhizal plants are typically generalists towards mycorrhizal fungi (Smith \& Read 2008). Less is known about the extent of specificity shown in the early developmental stages of dust-seeded plants growing in the field. Unravelling the processes that produce differences in specialization among lineages is of critical importance in biology (Thompson 2005). With respect to orchids, we need to understand the extent to which specificity towards fungi is a determinant of establishment in nature. If the myco-heterotrophic nutritional mode of orchid seedlings imposes transient specificity towards fungi with restricted distribution, then we may understand the mechanism that checks unlimited multiplication in dust-seeded plant lineages (Waterman \& Bidartondo 2008). Albeit based on a limited number of samples, McCormick et al.'s results (2004) suggest such a constraint for the orchid Tipularia discolor.

To further our knowledge of the extent of specificity and its role in determining establishment of orchid seedlings, we examined the fungal associations of germinating seeds, developing seedlings and adult plants of helleborine orchids in the genera Cephalanthera and Epipactis at forest sites in Europe. The helleborine orchids occur throughout Eurasia mostly in forest habitats. Most species are green, and hence, at least partially photosynthetic as adults, but they are known to subsidize their nutritional needs by epiparasitism of ectomycorrhizas (Gebauer \& Meyer 2003; Bidartondo et al. 2004; Abadie et al. 2006). As mature plants, these orchids are generalists towards fungi, although they do not form mycorrhizas with all of the fungi potentially available at a site. However, little is known about specificity during germination; forest-dwelling orchids, such as helleborines, have proven difficult to germinate both in vitro and in situ (van der Kinderen 1995; Yamato \& Iwase 2008). Here we test for specificity during germination and mycorrhizal development in Epipactis and Cephalanthera species within their own forest habitats by comparing mycorrhizal fungal diversity in germinating orchid seeds, orchid seedlings, mature orchids and tree roots. For C. longifolia, we also tested a nearby and a distant site without Cephalanthera.

\section{Materials and methods}

We collected seeds as soon as possible before outplanting them in seed packets (often the day before and always less than a month before) from mature capsules that were about to release or were releasing seeds (see Table 1 for details of sites and associated tree species). Seeds were removed from the capsules and examined under a dissecting microscope (40× magnification) to ensure the presence of mature pro-embryos. Seed packets were constructed using $50 \mu \mathrm{m}$ mesh nylon (Plastok) by folding and sealing a 1 $\times 1 \mathrm{~cm}$ pocket using an impulse heat sealer. One end of each packet was folded over and sealed to thread masonry line through. Approximately 75 seeds were placed in each packet for a total of 1500 seed packets. To minimize disturbance to roots and soil during burial, we used a

Table 1 Details of the locations where packets containing seeds of orchids were buried and harvested between 2004 and 2007 . Seeds were collected at the same site where they were buried, except at Newborough Warren. The column that lists orchid seeds buried shows in bold those taxa that achieved the highest germination

\begin{tabular}{|c|c|c|c|c|c|}
\hline Location & Dominant forest trees & Orchids in situ & Orchid seeds buried & $\begin{array}{l}\text { Burial } \\
\text { (months) }\end{array}$ & $\begin{array}{l}\text { Seed } \\
\text { packets }\end{array}$ \\
\hline $\begin{array}{l}\text { Chappett's Copse } 1 \\
\text { Hampshire, England }\end{array}$ & Fagus sylvatica & $\begin{array}{l}\text { Cephalanthera damasonium } \\
\text { Cephalanthera longifolia } \\
\text { Epipactis helleborine } \\
\text { Neottia nidus-avis. }\end{array}$ & $\begin{array}{l}\text { Cephalanthera damasonium } \\
\text { Cephalanthera longifolia } \\
\text { Epipactis helleborine }\end{array}$ & $\begin{array}{l}23 \\
23 \\
23\end{array}$ & $\begin{array}{l}200 \\
200 \\
100\end{array}$ \\
\hline $\begin{array}{l}\text { Chappett's Copse } 2 \\
\text { Hampshire, England }\end{array}$ & Fagus sylvatica & & Cephalanthera longifolia & 23 & 100 \\
\hline $\begin{array}{l}\text { Newborough Warren } \\
\text { Anglesey, Wales }\end{array}$ & Pinus nigra var. maritima & $\begin{array}{l}\text { Epipactis dunensis } \\
\text { Listera ovata }\end{array}$ & $\begin{array}{l}\text { Cephalanthera longifolia } \\
\text { (from Chappett's Copse 1) } \\
\text { Epipactis dunensis }\end{array}$ & $\begin{array}{l}16 \\
16\end{array}$ & $\begin{array}{l}100 \\
100\end{array}$ \\
\hline Betzenstein & Fagus sylvatica & Cephalanthera damasonium & Cephalanthera damasonium & 22 & 200 \\
\hline Oberfranken, Germany & Picea abies & $\begin{array}{l}\text { Cephalanthera rubra } \\
\text { Corallorhiza trifida } \\
\text { Epipactis atrorubens } \\
\text { Epipactis helleborine } \\
\text { Neottia nidus-avis }\end{array}$ & Epipactis atrorubens & 22 & 200 \\
\hline Boscodon & Pinus spp. & Cephalanthera longifolia & Cephalanthera longifolia & 36 & 100 \\
\hline Hautes-Alpes, France & Larix decidua & Epipactis helleborine & Epipactis helleborine & 36 & 100 \\
\hline $\begin{array}{l}\text { Lappeenranta } \\
\text { South Karelia, Finland }\end{array}$ & Pinus sylvestris & Epipactis helleborine & Epipactis helleborine & 20 & 100 \\
\hline
\end{tabular}


$3 \times 15 \mathrm{~cm}$ planting knife pushed into the soil and moved forward a few centimetres to slide down a packet using a metal hook. Then the knife was pulled out and the soil pushed back by hand. The loose end of the cord was attached to a flag or stake with a numbered metal tag. Packets were buried throughout each of the sites, at least $10 \mathrm{~cm}$ from each other, with a bias towards aggregations of mature orchids. These sites represent varied European forests and orchid assemblages where it was feasible to carry out long-term germination assays. With respect to soils, Chappett's is a rendzina with chalk and flint throughout, Betzenstein's is a brown earth over limestone, Newborough is a plantation on maritime sand dunes, Lappeenranta's is humus and fine sand over granite with high $\mathrm{pH}$ due to limestone dust from a nearby factory, and Boscodon's is a humus-rich forest soil over granite, gneiss and schist. The Cephalanthera and Epipactis species studied are distributed throughout Europe, with the exception of Epipactis dunensis that is restricted to Northern England and North Wales. At most of the sites, the area over which seed packets were deployed was $<100 \mathrm{~m}^{2}$ due to the sparse and restricted distribution of mature orchid plants. The exception was Chappett's Copse site 1 where Cephalanthera longifolia and C. damasonium are exceptionally abundant and widespread over an area $<500 \mathrm{~m}^{2}$. Chappett's Copse site 2, in contrast, lacks mature orchids and it is $c .100 \mathrm{~m}$ from site 1. At locations where the highest germination and development levels were observed (Table 1), we sampled orchid and tree mycorrhizas to facilitate comparison of the fungal symbiont flora of mature orchid and tree roots with that of the seedling stages. For this purpose, individual roots were excavated underneath five to 20 mature plants of each of the orchid species of which seed was buried. Ectomycorrhizal diversity was assessed by sampling roots from 20 soil samples per site, each of approximately $15 \mathrm{~mL}$ volume.

Seed packets were harvested by pulling the cord with its attached seed packet out of the soil. The seed packets were then sealed in plastic bags, stored on ice and processed within at most 4 days after harvest. For examination, packets were rinsed with tap water, opened with a mini-knife under a dissecting microscope, and each seed or seedling classified by a single observer as: (i) ungerminated seeds, (ii) germinating seeds, that is, seeds with seed coat (testa) cracked and embryo enlarged or emerging, or (iii) mycorrhizal seedlings (protocorms). All seedlings were collected with fine tweezers, flash-frozen in liquid nitrogen, lyophilized and weighed. From each seed packet, between one and six seeds in category (ii) or seedlings in category (iii), were placed singly in $300 \mu \mathrm{L}$ of cetyltrimethyl ammonium bromide (CTAB) buffer or $10 \mu \mathrm{L}$ of extraction solution (Sigma). From the largest seedlings, only a thin section was sampled. Fungi were identified using fungal-specific polymerase chain reaction (PCR) of the nuclear ribosomal internal transcribed spacer (nrITS) region following protocols described in Gardes \& Bruns (1993) modified for a silica-emulsion-binding and purification (Gene-Clean, Q-Biogene) or following a chemical DNA extraction and purification method (Extract-N-Amp, Sigma). In pilot studies, these two methods were found to have similar success rates. All positive $P C R$ products were purified with ExoSAP-IT (USB) and directly sequenced bidirectionally using BigDye 3.1 with an ABI 3730 (Applied Biosystems). All negative PCR products were used for a nested PCR, from 1:100 water dilutions, using PicoMaxx (Stratagene) or JumpStart (Sigma) with primers ITS1/ITS4 (White et al. 1990). Nested PCR products were directly sequenced bidirectionally. The remaining negative PCR products were used for PCR with tulasnelloid-specific ITS primers as described in Bidartondo et al. 2004. PCR products that could not be directly sequenced were cloned using TOPO TA (Invitrogen) and four cloned DNA amplicons were sequenced unidirectionally. All the DNA sequences from each site were compared to those in GenBank, grouped into lineages (e.g. family or genus) and visually aligned. A conservative $99 \%$ base-pair similarity cut-off was applied to define taxa. Similarly, species epithets were only assigned from GenBank accessions when our DNA sequences were nested within, and/or > 99\% identical to, named sporocarp sequences. Otherwise, only genus or family names were used. Phylogenetic species concepts from multilocus analyses are not available for the fungi detected, and most of the lineages detected are poorly represented in GenBank; thus, our nrITS DNA sequence taxon delimitation and species recognition must be considered tentative. Representative DNA sequences are deposited in GenBank (Accession nos EU668195-EU668308, Table S1, Supplementary material).

The roots of mature orchid plants were rinsed with tap water, sectioned by hand and examined with a microscope for mycorrhizal colonization. At least one section from as many roots as were found to be colonized was used to identify fungi as described for seeds and seedlings. The roots of trees were sampled from each soil core by placing the soil on a 1-mm mesh soil sieve, rinsing vigorously with tap water and manually collecting all ectomycorrhizal roots under a dissecting microscope. The ectomycorrhizas from each core were grouped by mantle appearance and at least one was sampled from each group; these single ectomycorrhizas were used to identify fungi as described for orchid seeds and seedlings.

From those seed packets that contained germinated seeds and/or seedlings at harvest, we carried out ANOvA tests using JMP 4.0.2 (SAS Institute) on the proportion of seeds at each developmental stage that associated with different fungal lineages. Proportion data was normalized using arcsine transformations and the data sets were balanced by removing randomly chosen blocks and/or 
merging fungal lineages by labelling them as 'other'. For each species at each site, we fit a least squares model using the number of samples as $y$ with sample type and fungus (Thelephoraceae, Cortinariaceae, Sebacinaceae, other) as effects. Sample-based rarefaction was used to construct fungal accumulation curves for seeds, seedlings, orchid mycorrhizas and ectomycorrhizas using EstimatesS $7+$ (Colwell 2006). The sample types were a soil core for ectomycorrhizas, a seed packet for germinating seeds and mycorrhizal seedlings, and a mature orchid plant for orchid mycorrhizas.

\section{Results}

The proportion of seeds that were germinating (enlarged embryos breaking the seed coat, Fig. 1b,c) varied from $63 \%$ for Cephalanthera longifolia at Chappett's Copse to 6\% for Epipactis atrorubens at Betzenstein. Across the three orchid species with highest germination, a uniform proportion of $1 \%$ of seeds had developed into mycorrhizal seedlings (Fig. 1d-f). Of the ungerminated seeds, $82 \%$ had apparently intact embryos (Fig. 1a) and the rest had collapsed embryos. In this study, we did not identify, or quantify the effects of, necrotrophs, saprotrophs or herbivores. Among seed packets, approximately one-fourth contained mycorrhizal

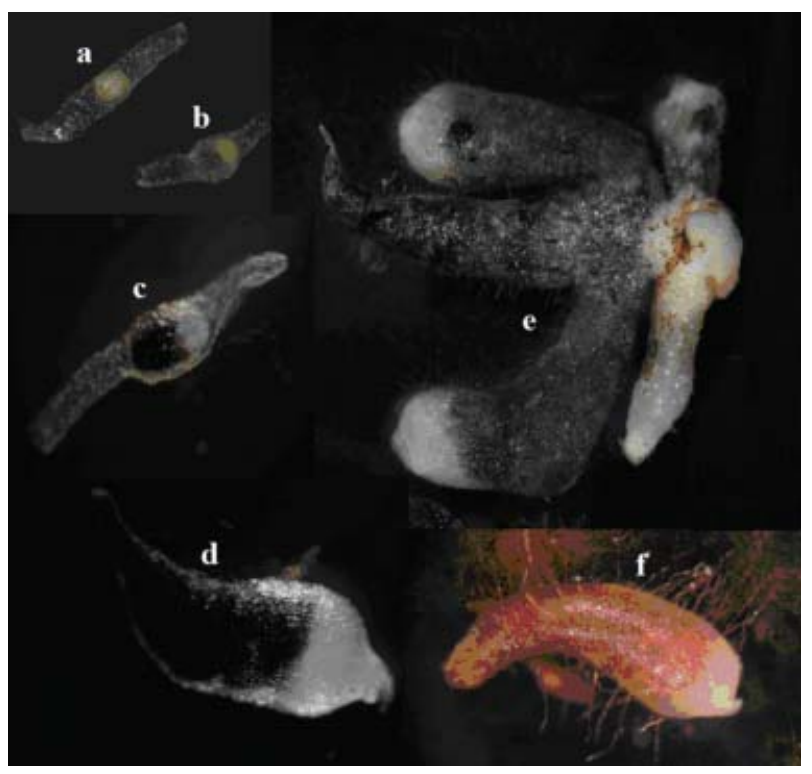

Fig. 1 Orchid seedling germination and development: (a) an ungerminated seed of Cephalanthera longifolia, (b) a germinating seed of $C$. longifolia colonized by Tomentella ramosissima, (c) a germinating seed of $C$. damasonium colonized by T. umbrinospora, (d) a mycorrhizal seedling of C. longifolia colonized by T. stuposa, (e) a branched mycorrhizal seedling of $C$. longifolia colonized by $T$. ramosissima, and (f) a mycorrhizal seedling of Epipactis atrorubens with a Thelephoraceae sp. Seed coat length is $c .1 \mathrm{~mm}$. Seedlings $\mathrm{d}-\mathrm{f}$ are $c .1 \mathrm{~cm}$ long. seedlings at harvest for both Cephalanthera and E. atrorubens. Mycorrhizal seedlings were observed in $<1 \%$ of packets of Epipactis dunensis at Newborough Warren and E. helleborine at Chappett's Copse site 1. We did not observe any germinated seeds at Lappeenranta or Boscodon. The seed packets were densely colonized by fungal hyphae and rhizomorphs (strands of aggregated hyphae) and in nearly $5 \%$ of them, ectomycorrhizas were able to penetrate through the mesh. The number of germinating seeds and mycorrhizal seedlings was negligible for all other species and absent at Chappett's Copse site 2. Overall, we analyzed a total of 772 root and seedling samples from which we obtained DNA sequence-based fungal identifications for $77 \%$ of germinating seeds, $91 \%$ of mycorrhizal seedlings, $88 \%$ of orchids and $85 \%$ of ectomycorrhizas. The vast majority of fungi detected on germinating seeds, mycorrhizal seedlings, mature orchids and ectomycorrhizas belong to ectomycorrhizal lineages. We detected multiple mycorrhizal fungi in less than $0.1 \%$ of germinated seeds, no mycorrhizal seedlings, and c. $5 \%$ of orchid roots. For E. atrorubens, the orchid root samples from Betzenstein were few; hence, we supplemented the data set with samples from nearby sites that were analyzed in a prior study (Bidartondo et al. 2004). ANova model tests were significant $(P<0.001)$ only at Chappett's Copse site 1 for both Cephalanthera spp.

\section{Fungal diversity in tree roots}

The numbers of fungal taxa present as symbionts were greatest in the ectomycorrhizal tree roots. Taxon accumulation curves for these (Fig. 2a-e) reveal an almost linear increase of numbers with increase in sample size. Prominent among the taxa observed were members of the Thelephoraceae (Table 2), but a number of other ectomycorrhizal taxa were present including Cortinarius, Dermocybe, Inocybe, Hebeloma, Russula, Sebacina and Tuber spp. It is evident from the shape of the taxon accumulation curves that the list of tree root associates at each site would continue to expand with more sampling. The site with the lowest diversity was Newborough Warren (Fig. 2d) with monospecific even-aged plantations of Corsican Pine (Pinus nigra var. maritima). Here there was a less diverse range of thelephoroid fungi, a greater number of Sebacina lineages, as well as two Russula and a Suillus species (Table 3). The greatest diversity of ectomycorrhizal lineages was observed in the natural beech forests of Betzenstein (Table 4).

\section{Fungal diversity in germinating orchid seeds}

While supporting a lower diversity of fungal symbionts than the tree roots, it is apparent both from the taxon accumulation curves (Fig. 2a-e) and the fungal taxon identification data (Tables 2 and 3) that germination of Cephalanthera damasonium and C. longifolia occurred with a 

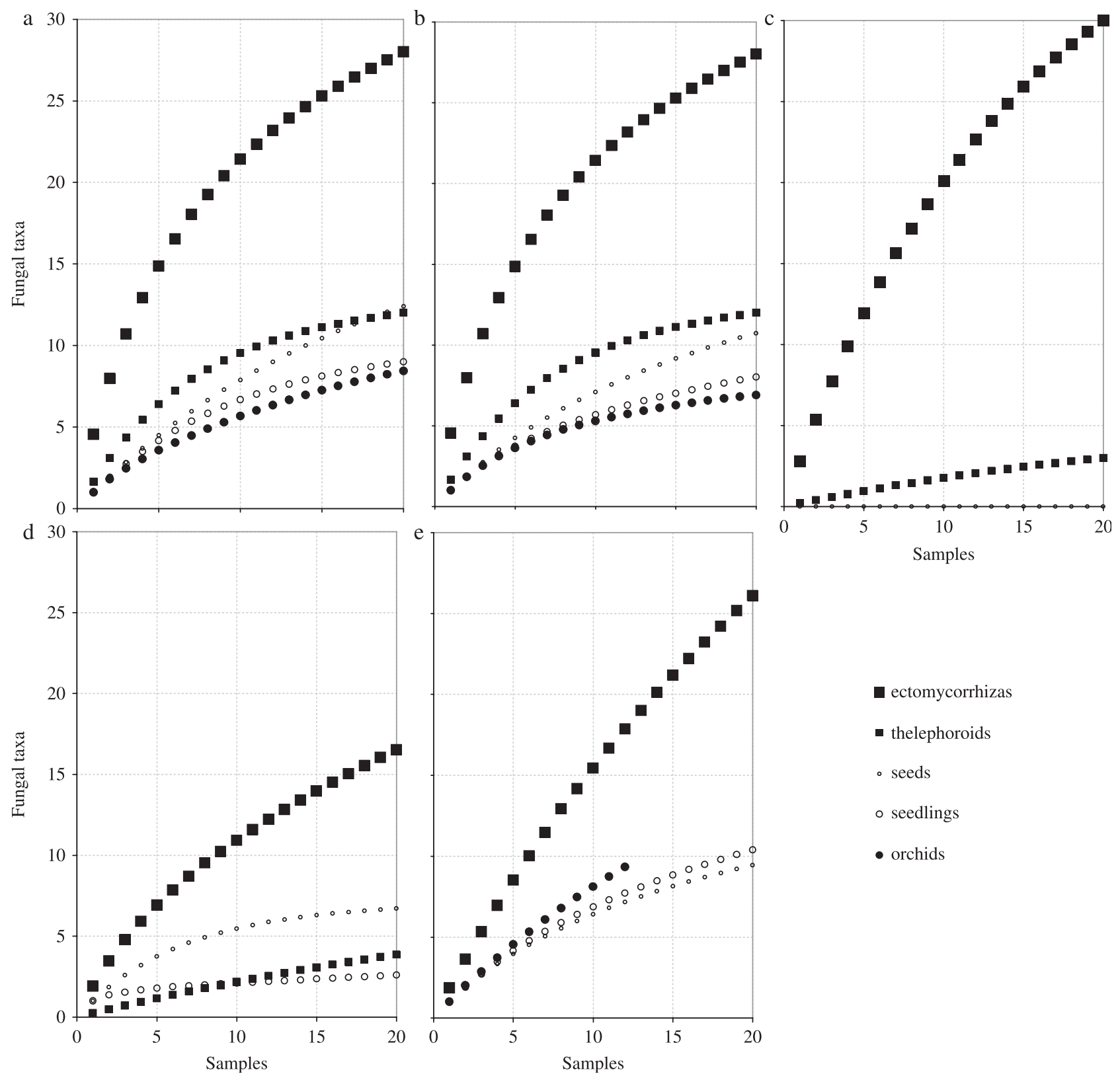

Fig. 2 Fungal taxon accumulation curves at four different locations. Squares represent tree root samples and circles represent orchid samples; these are ectomycorrhizas in soil cores (large black squares), germinating orchid seeds in seed packets (small open circles), mycorrhizal orchid seedlings in seed packets (large open circles) and mature mycorrhizal orchid roots in the soil (filled circles). In curves $\mathrm{a}-\mathrm{d}$, ectomycorrhizas with thelephoroid fungi are also shown separately as small black squares. (a) Chappett's Copse site 1 and Cephalanthera damasonium. (b) Chappett's Copse site 1 and C. longifolia. (c) Chappett's Copse site 2 and C. longifolia (seeds from Chappett's Copse site 1). (d) Newborough Warren and C. longifolia (seeds from Chappett's Copse site 1). (e) Betzenstein and Epipactis atrorubens. A sample corresponds to either a soil core (ectomycorrhizas), a seed packet (germinating seeds and mycorrhizal seedlings) or a mature orchid plant (orchid mycorrhizas).

high proportion of the fungi identified in the tree roots. Thus, in addition to a number of Tomentella and Pseudotomentella, germination of seedlings of these orchids was achieved with Inocybe and Sebacina at Newborough (Table 3) and also with a Cortinarius at Chappett's Copse. At Betzenstein,
E. atrorubens germinated with a small subset of the thelephoroid fungi associated with the tree roots but also with a number of cortinarioid fungi, several Sebacina, some Lactarius and Russula and with a number of athelioid and corticioid fungi (Table 4).

\section{(c) 2008 The Authors}

Journal compilation @ 2008 Blackwell Publishing Ltd 
Table 2 Mycorrhizal fungi detected in tree ectomycorrhizas, germinating orchid seeds and mycorrhizal orchid seedlings at Chappett's Copse, England, indicated by grey boxes. Columns 3-9 correspond to site 1 . The last column corresponds to site 2 (where there were neither mature orchids nor seed packets with germinated seeds or mycorrhizal seedlings). C.l., Cephalanthera longifolia; C.d., Cephalanthera damasonium

\begin{tabular}{|c|c|c|c|c|c|c|c|c|c|}
\hline Fungi lineages & Taxa & $\begin{array}{l}\text { Ectomycorrhizas } \\
\text { site } 1\end{array}$ & $\begin{array}{l}\text { C.d. } \\
\text { seeds }\end{array}$ & $\begin{array}{l}\text { C.l. } \\
\text { seeds }\end{array}$ & $\begin{array}{l}\text { C.d. } \\
\text { seedlings }\end{array}$ & $\begin{array}{l}\text { C.l. } \\
\text { seedlings }\end{array}$ & $\begin{array}{l}\text { C.d. } \\
\text { plants }\end{array}$ & $\begin{array}{l}\text { C.l. } \\
\text { plants }\end{array}$ & $\begin{array}{l}\text { ectomycorrhizas } \\
\text { site } 2\end{array}$ \\
\hline Thelephoraceae & Pseudotomentella 1 & & & & & & & & \\
\hline Thelephoraceae & Pseudotomentella 2 & & & & & & & & \\
\hline Thelephoraceae & Tomentella galzinii & & & & & & & & \\
\hline Thelephoraceae & Tomentella lapidum & & & & & & & & \\
\hline Thelephoraceae & Tomentella ramosissima & & & & & & & & \\
\hline Thelephoraceae & Tomentella stuposa & & & & & & & & \\
\hline Thelephoraceae & Tomentella umbrinospora & & & & & & & & \\
\hline Thelephoraceae & Tomentella 1 & & & & & & & & \\
\hline Thelephoraceae & Tomentella 2 & & & & & & & & \\
\hline Thelephoraceae & Tomentella 3 & & & & & & & & \\
\hline Thelephoraceae & Tomentella 4 & & & & & & & & \\
\hline Thelephoraceae & Tomentella 5 & & & & & & & & \\
\hline Thelephoraceae & Tomentella 6 & & & & & & & & \\
\hline Thelephoraceae & Tomentella 7 & & & & & & & & \\
\hline Thelephoraceae & Tomentella 8 & & & & & & & & \\
\hline Thelephoraceae & Tomentella 9 & & & & & & & & \\
\hline Thelephoraceae & Tomentella 10 & & & & & & & & \\
\hline Thelephoraceae & Tomentella 11 & & & & & & & & \\
\hline Thelephoraceae & Tomentella 12 & & & & & & & & \\
\hline Thelephoraceae & Singletons & & & & & & & & \\
\hline Cortinariaceae & Cortinarius & & & & & & & & \\
\hline Cortinariaceae & Dermocybe olivaceopicta & & & & & & & & \\
\hline Cortinariaceae & Hebeloma velutipes & & & & & & & & \\
\hline Cortinariaceae & Inocybe cf. glabripes & & & & & & & & \\
\hline Cortinariaceae & Inocybe rimosa & & & & & & & & \\
\hline Cortinariaceae & Inocybe 1 & & & & & & & & \\
\hline Cortinariaceae & Inocybe 2 & & & & & & & & \\
\hline Cortinariaceae & Inocybe 3 & & & & & & & & \\
\hline Cortinariaceae & Inocybe 4 & & & & & & & & \\
\hline Cortinariaceae & Inocybe 5 & & & & & & & & \\
\hline Sebacinaceae & Sebacina 1 & & & & & & & & \\
\hline Sebacinaceae & Sebacina 2 & & & & & & & & \\
\hline Sebacinaceae & Sebacina 3 & & & & & & & & \\
\hline Sebacinaceae & Singletons & & & & & & & & \\
\hline Ascomycota & Leptodontidium orchidicola & & & & & & & & \\
\hline Ceratobasidiaceae & Ceratobasidium & & & & & & & & \\
\hline Dothideomycetes & Cenococcum & & & & & & & & \\
\hline Helvellaceae & Balsamia & & & & & & & & \\
\hline Hymenogastraceae & Hymenogaster & & & & & & & & \\
\hline Pezizaceae & Peziza succosa & & & & & & & & \\
\hline Pezizaceae & Unknown & & & & & & & & \\
\hline Pyronemataceae & Genea & & & & & & & & \\
\hline Russulaceae & Russula fellea & & & & & & & & \\
\hline Tricholomataceae & Tricholoma scalpturatum & & & & & & & & \\
\hline Tuberaceae & Tuber scruposum & & & & & & & & \\
\hline Tuberaceae & Tuber brumale & & & & & & & & \\
\hline Tuberaceae & Tuber puberulum & & & & & & & & \\
\hline Tuberaceae & Tuber & & & & & & & & \\
\hline
\end{tabular}


Table 3 Mycorrhizal fungi detected in tree ectomycorrhizas, germinating orchid seeds and mycorrhizal orchid seedlings at Newborough Warren, Wales, indicated by grey boxes. At this site, we planted seed packets containing Cephalanthera longifolia (C.l.) seeds from Chappett's Copse site 1. Cephalanthera does not occur at this site. Epipactis dunensis (last column) occurs naturally at Newborough Warren

\begin{tabular}{|c|c|c|c|c|c|}
\hline Fungi lineages & Taxa & Ectomycorrhizas & C.l. seeds & C.l. seedlings & E. dunensis plants \\
\hline Thelephoraceae & Pseudotomentella A & & & & \\
\hline Thelephoraceae & Pseudotomentella B & & & & \\
\hline Thelephoraceae & Tomentella lapidum & & & & \\
\hline Thelephoraceae & Tomentella ramosissima & & & & \\
\hline Thelephoraceae & Tomentella A & & & & \\
\hline Thelephoraceae & Tomentella B & & & & \\
\hline Cortinariaceae & Cortinarius & & & & \\
\hline Cortinariaceae & Inocybe A & & & & \\
\hline Sebacinaceae & Sebacina epigaea & & & & \\
\hline Sebacinaceae & Sebacina I & & & & \\
\hline Sebacinaceae & Sebacina A & & & & \\
\hline Sebacinaceae & Sebacina B & & & & \\
\hline Sebacinaceae & Sebacina 4 & & & & \\
\hline Pyronemataceae & Wilcoxina & & & & \\
\hline Pezizaceae & Pezizaceae A & & & & \\
\hline Pezizaceae & Pezizazeae B & & & & \\
\hline Russulaceae & Russula A & & & & \\
\hline Russulaceae & Russula B & & & & \\
\hline Suillaceae & Suillus luteus & & & & \\
\hline Tuberaceae & Tuber & & & & \\
\hline
\end{tabular}

\section{Fungal diversity in mycorrhizal orchid seedlings and mature plants}

It is a striking feature of Cephalanthera seedlings at both Chappett's Copse (Table 2) and Newborough Warren (Table 3) that in the post-germination phase, by which time the tissues of the orchid are developing, the diversity of fungal taxa that are present as mycorrhizal associates is much reduced relative to that seen either in the tree roots, the mature orchids or in the orchid seeds when germination is initiated. Thus, mycorrhizal seedlings of both Cephalanthera species contain only a subset of the thelephoroid fungi capable of stimulating germination and lack altogether the cortinarioid and sebacinoid fungi that were found in association with the earlier life cycle stage (i.e. germinating seeds) and later stage (i.e. mature plants). However, we did not find significant differences in seed germination rate among the three fungal lineages detected in germinating seeds of Cephalanthera. The situation in E. atrorubens at Betzenstein is somewhat different. There is a much greater similarity between the fungi present at the two developmental stages. The restricted range of thelephoroid and cortinarioid fungi seen in the germinating seeds is also, for the most part, retained in the mycorrhizal seedlings (Table 4, Fig. 2e). The thelephoroid, cortinarioid and most of the sebacinoid fungi observed at these two developmental stages were not recorded in the mature plants. In this orchid there are also several ascomycete lineages present in the mycorrhizal seedlings, some of which were seen neither in the germinating seeds nor in mature orchid plants. In fact, there was a significant difference (ANOva $P=0.001$ ) among fungal lineages at germination, leading to overrepresentation of ascomycetes among mycorrhizal orchid seedlings. However, we found no significant difference in dry weight between mycorrhizal seedlings associated with ascomycetes and mycorrhizal seedlings associated with other fungi. At Newborough Warren, mature plants (and six mycorrhizal seedlings, data not shown) of native $E$. dunensis associated with a broader and largely different set of fungi than the fungi used by seedlings of alien C. longifolia (seeds from Chappett's Copse 1 buried at Newborough Warren).

\section{Discussion}

In this study, we considered some of the factors that may be involved in checking what Darwin referred to as the potential for 'unlimited multiplication' of orchids. We present novel evidence bearing upon four aspects of recruitment of helleborine orchids: (i) the plants are sustained by a distinctive phylogenetic subset of those mycorrhizal fungi that are potentially available to them at a site throughout their life cycle; (ii) among this subset, a high proportion of fungi are capable of initiating germination of the orchids' dust seeds; (iii) a much smaller subset of the fungi capable of initiating germination are involved in 
Table 4 Mycorrhizal fungi detected in tree ectomycorrhizas, germinating orchid seeds and mycorrhizal orchid seedlings at Betzenstein, Germany, indicated by grey boxes. E.a., Epipactis atrorubens

\begin{tabular}{|c|c|c|c|c|c|}
\hline Fungi lineages & Taxa & Ectomycorrhizas & E.a. seeds & E.a. seedlings & E.a. plants \\
\hline Thelephoraceae & Tomentella I & & & & \\
\hline Thelephoraceae & Tomentella II & & & & \\
\hline Thelephoraceae & Tomentella III & & & & \\
\hline Thelephoraceae & Tomentella IV & & & & \\
\hline Thelephoraceae & Tomentella $\mathrm{V}$ & & & & \\
\hline Thelephoraceae & Tomentella VI & & & & \\
\hline Thelephoraceae & Tomentella VII & & & & \\
\hline Thelephoraceae & Tomentella VIII & & & & \\
\hline Thelephoraceae & Tomentella IX & & & & \\
\hline Thelephoraceae & Tomentella X & & & & \\
\hline Cortinariaceae & Hebeloma & & & & \\
\hline Cortinariaceae & Cortinarioid & & & & \\
\hline Cortinariaceae & Cortinarius & & & & \\
\hline Cortinariaceae & Inocybe & & & & \\
\hline Sebacinaceae & Sebacina incrustans & & & & \\
\hline Sebacinaceae & Sebacina I & & & & \\
\hline Sebacinaceae & Sebacina II & & & & \\
\hline Sebacinaceae & Sebacina III & & & & \\
\hline Sebacinaceae & Sebacina IV & & & & \\
\hline Sebacinaceae & Sebacina $\mathrm{V}$ & & & & \\
\hline Sebacinaceae & Sebacina VI & & & & \\
\hline Sebacinaceae & Sebacina VII & & & & \\
\hline Sebacinaceae & Sebacina VIII & & & & \\
\hline Atheliaceae & Amphinema & & & & \\
\hline Atheliaceae & Piloderma & & & & \\
\hline Clavulinaceae & Clavulinoid & & & & \\
\hline Corticiaceae & Sistotrema I & & & & \\
\hline Corticiaceae & Sistotrema II & & & & \\
\hline Cortinariaceae & Dermocybe & & & & \\
\hline Dothideomycetes & Cenococcum & & & & \\
\hline Helotiaceae & Meliniomyces variabilis & & & & \\
\hline Hygrophoraceae & Hygrophorus discoxanthus & & & & \\
\hline Pezizaceae & Hydnobolites I & & & & \\
\hline Pezizaceae & Hydnobolites II & & & & \\
\hline Pyronemataceae & Genea & & & & \\
\hline Pyronemataceae & Geopora & & & & \\
\hline Pyronemataceae & Pyronemataceae & & & & \\
\hline Pyronemataceae & Wilcoxina & & & & \\
\hline Russulaceae & Lactarius deliciosus & & & & \\
\hline Russulaceae & Lactarius mitissimus & & & & \\
\hline Russulaceae & Lactarius I & & & & \\
\hline Russulaceae & Lactarius II & & & & \\
\hline Russulaceae & Russula vinosa & & & & \\
\hline Russulaceae & Russula & & & & \\
\hline Tuberaceae & Tuber rufum & & & & \\
\hline
\end{tabular}

enabling the greatest extent of seedling development; and (iv) throughout their life cycle, these orchids are almost without exception associated with fungi that are ectomycorrhizal associates of tree roots. It is clear from these results that specificity towards a subset of the fungi that are obligately restricted to associations with forest trees is a major factor restricting unlimited multiplication in these plants.
All of our fungal taxon accumulation curves indicate that the trees under which the orchids grow are able to form mycorrhizal associations with a considerably greater phylogenetic range of fungi than the orchids; Cephalanthera damasonium and C. longifolia are largely restricted to thelephoroid fungi. Natural resource managers and conservationists frequently seek to characterize the habitat requirements of rare plants across sites. Some studies have 
attempted to define these conditions for orchids by studying the temporal (Whigham et al. 2006) and spatial (Batty et al. 2001; Jacquemyn et al. 2006, 2007; Diez 2007) dynamics of their germination in the field without identifying the fungi involved. However, from our study the answer hinges mainly on the availability, at the site in question, of the narrowest group of fungi necessary for completion of the plant's life cycle.

Zelmer et al. (1996) hypothesized that the seedlings of many forest orchids were associated with ectomycorrhizal fungi that could not be cultivated in vitro. Our results confirm this view. It appears that the relative scarcity of fungi, particularly representatives of the Thelephoraceae, that are critical for germination and seedling development, can explain the absence of a mature orchid at a site. This would explain the lack of $C$. longifolia at a site such as Chappett's Copse 2 in contrast to its abundant presence at the Thelephoraceae-rich Chappett's Copse 1 site which is only c. $100 \mathrm{~m}$ away. Similarly, the abundance of thelephoroid fungi at Newborough Warren would provide an explanation for the ability of $C$. longifolia to germinate at this site despite the lack of adults of this plant. The absence of naturally occurring plants of this species at Newborough is thus most likely attributable to a lack of seed supply rather than a failure of seed germination.

The observed differentiation between the relatively large number of distantly related fungi capable of initiating germination and the smaller subset of closely related fungi capable of taking the process further is likely to be of particular significance in the context of orchid 'multiplication.' If, as what appears to be the case in myco-heterotrophs of the Ericaceae, the trigger for initiation of germination is a diffusible compound released by compatible fungi (Bruns \& Read 2000), then the low level of specialization at the germination phase must reflect a lack of specificity in the initial signalling exchanges. The post-germination loss of so many protocorms that had been stimulated to initiate development can be seen as a 'cost' attributable to this lack of precision in the symbiont recognition process. According to this interpretation, the smaller number of protocorms able to progress further into seedling development would do so on the basis of greater physiological compatibility with their respective mycorrhizal fungal partners. If this is the case, the production by the orchid of large numbers of seeds is the cost of being able to effectively screen the environment for the most physiologically compatible species or genotypes of fungal symbionts.

In conclusion, while germination of the helleborine orchids in the natural environment can be initiated relatively readily, their requirements for development beyond the germination phase are more specialized. Thus, mycorrhizal specificity during symbiotic development may restrict the multiplication of these prolific dust-seed producing lineages in nature.

\section{Acknowledgements}

The authors thank the following: the Natural Environment Research Council for grant NER/B/S/2003/00255 to D.J.R. and the Bentham-Moxon Trust for a grant to M.I.B.; Dirk Redecker and two anonymous reviewers for comments; the Hampshire and Isle of Wight Wildlife Trust for site access; Peter Carey (Centre for Ecology and Hydrology, Monks Wood) for help selecting sites; Kimmo Saarinen (Etelä-Karjalan Allergia-ja Ympäristöinstituutti) for setting up and harvesting the Finnish experiment; Gerhard Gebauer, Cornelia Meyer, Marcus Stöckel and Katja Zimmer (Universität Bayreuth) for helping to set up and harvest the German experiment; and Luis Inda (Universidad de Zaragoza) and Cornelia Meyer for help setting up the English experiment.

\section{References}

Abadie J-C, Püttsepp U, Gebauer G, Faccio A, Bonfante P, Selosse M-A (2006) Cephalanthera longifolia (Neottieae, Orchidaceae) is mixotrophic: a comparative study between green and non-photosynthetic individuals. Canadian Journal of Botany, 84, 1462-1477.

Arditti J, Ghani AKA (2000) Numerical and physical properties of orchid seeds and their biological implications. New Phytologist, 145, 367-421.

Batty AL, Dixon KW, Brundrett M, Sivasithamparam K (2001) Constraints to symbiotic germination of terrestrial orchid seed in a Mediterranean bushland. New Phytologist, 152, 511-520.

Bidartondo MI (2005) Tansley review - the evolutionary ecology of myco-heterotrophy. New Phytologist, 167, 335-352.

Bidartondo MI, Burghardt B, Gebauer G, Bruns TD, Read DJ (2004) Changing partners in the dark: isotopic and molecular evidence of ectomycorrhizal liaisons between forest orchids and trees. Proceedings of the Royal Society B: Biological Sciences, 271, 1799-1806.

Bruns TD, Read DJ (2000) In vitro germination of nonphotosynthetic myco-heterotrophic plants stimulated by fungi isolated from the adult plants. New Phytologist, 148, 335-342.

Colwell R (2006) EstimatesS: statistical estimation of species richness and shared species from samples, version 8 . Persistent URL < purl.oclc.org/estimates>.

Darwin C (1862) On the Various Contrivances by which British and Foreign Orchids are Fertilized by Insects, and on the Good Effects of Intercrossing. John Murray, London.

Diez JM (2007) Hierarchical patterns of symbiotic orchid germination linked to adult proximity and environmental gradients. Journal of Ecology, 95, 159-170.

Gardes M, Bruns TD (1993) ITS primers with enhanced specificity for basidiomycetes: application to the identification of mycorrhizae and rusts. Molecular Ecology, 2, 113-118.

Gebauer G, Meyer M (2003) $15 \mathrm{~N}$ and $13 \mathrm{C}$ natural abundance of autotrophic and myco-heterotrophic orchids provides insight into nitrogen and carbon gain from fungal association. New Phytologist, 160, 209-223.

Jacquemyn H, Brys R, Vandepitte K, Honnay O, Roldán-Ruiz I (2006) Fine-scale genetic structure of life history stages in the fooddeceptive orchid Orchis purpurea. Molecular Ecology, 15, 2801-2808.

Jacquemyn H, Brys R, Vandepitte K, Honnay O, Roldán-Ruiz I, Wiegand T (2007) A spatially explicit analysis of seedling recruitment in the terrestrial orchid Orchis purpurea. New Phytologist, 176, 448-459.

van der Kinderen G (1995) Observations on in situ germination of Epipactis helleborine (L.) Crantz. Lindleyana, 10, 223-231. 
Leake JR (1994) Tansley review - the biology of myco-heterotrophic ('saprophytic') plants. New Phytologist, 127, 171-216.

McCormick MK, Whigham DF, O'Neill J (2004) Mycorrhizal diversity in photosynthetic terrestrial orchids. New Phytologist, 163, 425-438.

Smith SE, Read DJ (2008) Mycorrhizal Symbiosis, 3rd edn. Academic Press, San Diego, California.

Thompson JN (2005) The Geographic Mosaic of Coevolution. University of Chicago Press, Chicago.

Waterman R, Bidartondo MI (2008) Deception above, deception below: linking pollination and mycorrhizal biology of orchids. Journal of Experimental Botany, 59, 1085-1096.

Whigham DF, O'Neill JP, Rasmussen HN, Caldwell BA, McCormick MK (2006) Seed longevity in terrestrial orchids - potential for persistent in situ seed banks. Biological Conservation, 129, 24-30.

White TJ, Bruns TD, Lee S, Taylor JW (1990) Amplification and direct sequencing of fungal ribosomal RNA genes for phylogenetics. In: PCR Protocols: a Guide to Methods and Applications (eds Innis MA, Gelfand DH, Sninsky JJ, White TJ), pp. 315-322. Academic Press, San Diego, California.

Yamato M, Iwase K (2008) Introduction of asymbiotically propagated seedlings of Cephalanthera falcata (Orchidaceae) into natural habitat and investigation of colonized mycorrhizal fungi. Ecological Research, 23, 329-337.

Zelmer CD, Cuthbertson L, Currah RS (1996) Fungi associated with terrestrial orchid mycorrhizas, seeds and protocorms. Mycoscience, 37, 439-448.
Martin Bidartondo is a senior lecturer at Imperial College London and the Royal Botanic Gardens, Kew. Sir David Read is an emeritus professor at the University of Sheffield. The authors share an interest in the roles of mycorrhizas in natural ecosystems.

\section{Supplementary material}

The following supplementary material is available for this article:

Table S1 Fungi detected at each location with putative lineage and taxon names, representative DNA sequence identifier and GenBank accession number. Chappett's Corpse sites 1 and 2 have been combined.

This material is available as part of the online article from: http://www.blackwell-synergy.com/doi/abs/

10.1111/j.1365-294X.2008.03848.x

(This link will take you to the article abstract).

Please note: Blackwell Publishing are not responsible for the content or functionality of any supplementary materials supplied by the authors. Any queries (other than missing material) should be directed to the corresponding author for the article. 